\title{
Histochemical and Immunohistochemical Studies on Intraepithelial Nerve Fibers in the Ejaculatory Duct of the Monkey (Macacus Fuscatus)
}

\author{
RYUJI YOKOYAMA \\ Department of Anatomy, Kurume University School of Medicine, Kurume, 830 Japan
}

Received for publication July 24, 1989

\begin{abstract}
Summary: With special attention to intraepithelial nerve supply, the distribution of peripheral nerve fibers in the ejaculatory duct of the monkey (Macacus fuscatus) was examined by histochemical and immunohistochemical methods and conventional transmission electron microscopic (TEM) method. The conventional TEM study has suggested that there are two types of intraepithelial nerve fibers, i.e. cholinergic and peptidergic. Acetylcholinesterase $(\mathrm{AChE})$-positive nerve fibers which were seen by means of light microscopy (LM) as surrounding the epithelium were revealed to be present intraepithelially by means of TEM examination. Neuropeptide Y (NPY)-like immunoreactive nerve fibers were richly distributed in the ejaculatory duct with a dense plexus spreading just beneath the epithelium. The immunoreactive nerves appeared, in part, to enter the epithelium. Substance P (SP)-and calcitonin gene-related peptide (CGRP)-like immunoreactive nerve fibers were found to be present to a moderate extent in the ejaculatory duct; some of them entered the interior of the epithelium to extend their nerve terminals to its free surface. Neural elements clearly immunoreactive for tyrosine hydroxylase (TH) and vasoactive intestinal peptide (VIP) could not be found in the ejaculatory duct, except for the surroundings of the blood vessels. Possible functional roles of these intraepithelial nerves were discussed on the basis of their distribution pattern.
\end{abstract}

Key words: ejaculatory duct - intraepithelial nerve - acetylcholinesterase neuropeptide $\mathrm{Y}$ - substance $\mathrm{P}$ - calcitonin gene-related peptide

\section{Introduction}

The ejaculatory duct is defined as a tubular seminal tract which begins at the junction of the deferent duct and the excretory duct of the seminal vesicle and ends at its opening into the urethra. Subsequently, the duct runs ventral and caudal in the para-urethral connective tissue of the prostate gland and opens into the urethra on the lateral side of the colliculus seminalis.

The ejaculatory duct has been so far investigated less thoroughly than other male genital organs or tracts. Felix (1901) was first to describe combined macroscopic and microscopic anatomy of the ejaculatory duct of adult human being. Thereafter, Lowsley (1912), Burkl (1953) and Aumüller (1979) carried out ontogenic studies on human ejaculatory duct. Cossu and his co-workers (1983) observed ultrastructure of the epithelial cells of human ejaculatory duct.

Respecting the innervation of the ejaculatory duct, Nobuta (1949) examined human uro-genital organs including the ejaculatory duct by use of silver-impregnation method and briefly described the presence of intraepithelial nerve terminals in this 
duct. Murakami and his co-workers (1988) demonstrated, by means of transmsision electron microscopic (TEM) methodology, the nerve fibers located intraepithelially in the monkey ejaculatory duct. However, the histochemical characteristics of these intraepithelial nerve fibers remained obscure.

Recent immunohistochemical studies revealed various chemical substances locating in neurons, and enabled us to reevaluate the significance of the innervation of various organs.

The aim of the present study was to clarify the nature and the mode of distribution of nerve fibers located in the mucosal epithelium of the monkey ejaculatory duct.

\section{Materials and Methods}

Adult male Japanese monkeys (10-15 $\mathrm{kg}$ ) were used in this study. Under ketamine hydrochloride anesthesia, the animals were perfused intravascularly with fixatives described just below. Tissue blocks containing the ejaculatory duct were excised and immersed for 4-12 hours in the same fixatives used in perfusion. As fixatives, $2 \%$ paraformaldehyde and $2.5 \%$ glutaraldehyde mixture in $0.1 \mathrm{M}$ cacodylate buffer ( $\mathrm{pH} 7.3,1 / 2$ Karnovsky's fixative), cold $\left(4^{\circ} \mathrm{C}\right) 1 / 4$ Karnovsky's fixative ( $\mathrm{pH} 7.3$ ), and cold $2 \%$ paraformaldehyde and $0.2 \%$ picric acid mixture in $0.1 \mathrm{M}$ phosphate buffer ( $\mathrm{pH} 7.3$, Zamboni's fixative) were used for conventional TEM study, histochemical study and immunohistochemical study, respectively.

\section{Conventional TEM study}

The fixed tissue blocks were cut into slices $200-300 \mu \mathrm{m}$ thick on an autochopper and rinsed in $0.1 \mathrm{M}$ phosphate buffer (PB) containing $7.5 \%$ sucrose. The specimens were post-fixed in $2 \% \mathrm{OsO}_{4}$ buffered with $0.1 \mathrm{M}$ phosphate ( $\mathrm{pH} 7.4$ ) for 2 hours, de- hydrated in an ascending series of acetone (50-100\%), and then embedded in epoxy resin. Ultrathin sections were made with a diamond knife on a Reichert-Jung Ultramicrotome, doubly stained with uranyl acetete and lead citrate, and examined with TEM (JEM-2000EX). Semithin sections $(1-1.5 \mu \mathrm{m})$ were prepared for light microscopic (LM) examination and stained with toluidine blue.

\section{Histochemical study (AChE reaction)}

For LM, the tissue blocks were incubated in $0.1 \mathrm{M}$ phosphate buffer (PB, $\mathrm{pH}$ 7.4) containing $7.5 \%, 10 \%, 15 \%$ and $20 \%$ sucrose at $4^{\circ} \mathrm{C}$ for $6-12$ hours respectively. Then, they were quickly frozen with liquid $\mathrm{CO}_{2}$ and cut on a cryostat into frozen sections $15-20 \mu \mathrm{m}$ thick. The free floating sections were stored in PB containing $7.5 \%$ sucrose at $4^{\circ} \mathrm{C}$. For TEM examination, tissue sections $100-200 \mu \mathrm{m}$ thick were made on an autochopper and rinsed several times with PB containig $7.5 \%$ sucrose.

$\mathrm{AChE}$ staining was performed for the LM and TEM specimens according to Karnovsky-Roots' method modified by Tago et al. (1986). The specimens for the TEM examination were processed according to the method described above.

\section{Immunohistochemical study}

The tissue blocks were cut into frozen sections $15-20 \mu \mathrm{m}$ thick on a cryostat after cryoprotection.

\section{a. Treatment prior to immunostaining}

The free floating sections were 1) rinsed several times with $\mathrm{PB}, \mathrm{2}$ ) incubated for $1-3$ days in $\mathrm{PB}$ containing $0.3 \%$ Triton $\mathrm{X}-100$ at $\left.4^{\circ} \mathrm{C}, 3\right)$ rnised with $0.1 \mathrm{M}$ phosphate buffer saline (PBS, $\mathrm{pH} 7.4$ ), 4) incubated for $30 \mathrm{~min}$ in PBS containing $0.3 \% \mathrm{H}_{2} \mathrm{O}_{2}$ at room temperature, 5) rinsed with PBS, 6) incubated for 1 hour in PBS containing $10 \%$ goat serum (Dakopatts, Denmark) at $4^{\circ} \mathrm{C}$. 


\section{$b$. Immunostaining procedure}

The specimens were 1) incubated 3-4 days in primary antisera diluted with PBS containing both $1 \%$ bovine serum albumin (BSA, Sigma, USA) and $0.1 \% \mathrm{NaN}_{3}$ at $4^{\circ} \mathrm{C}$ for 3-4 days at each optimum dilution (see below), 2) rinsed with PBS containing $0.1 \% \mathrm{BSA}$ and $0.1 \% \mathrm{NaN}_{3}, 3$ ) incubated at $4^{\circ} \mathrm{C}$ for 1 hour in biotinylated secondary antisera (antirat IgG, raised in donkey, Amersham, England; anti-rabbit IgG, raised in sheep, Amersham, England) diluted 1:100-1:200 with the diluent used in the process (1), 4) rinsed with PBS containing $0.1 \%$ BSA, 5) incubated in streptavidin-biotinylated-HRP complex (ABC, Amersham, England) diluted to 1: 100-1:200 with PBS containing 1\% BSA at $4^{\circ} \mathrm{C}$ for 1 hour, 6) rinsed as under (4), and 7) stained with 3,3-diaminobenzidine tetrahydrochloride (DAB) after a brief incubation in $0.05 \mathrm{M}$ Tris buffer ( $\mathrm{pH} \mathrm{7.6).}$

Following primary antisera were used in this study; 1) anti-substance $\mathrm{P}$ (SP) anti-serum (monoclonal, raised in rat, 1: 4000 dilution, Sera-Lab, England), 2) anticalcitonin gene-related peptide (CGRP) antiserum (polyclonal, raised in rabbit, 1:3000 dilution, Amersham, England), 3) anti-neuropeptide Y (NPY) antiserum (polyclonal, raised in rabbit 1:2000 dilution, Cambridge, England), 4) anti-vasoactive intestinal peptide (VIP) antiserum (polyclonal raised in rabbit, 1:2500 dilution, Milab Malmö, Sweden) and antityrosine hydroxylase (TH) antiserum (polyclonal, raised in rabbit, 1:6000 dilution, provided by Dr. I. Nagatsu).

To check the specificity of immunoreactivity for SP, CGRP and NPY, the control studies including absorption tests were performed, and any immunoreactions for these peptides were not observed. The specificity of both the anti-VIP and the anti-TH antiserum has been already demonstrated (VIP: Ando, 1988; TH: Nagatsu et al. 1983).

\section{Results}

\section{LM and conventional TEM study}

For most part, the ejaculatory duct possessed a narrow lumen which was delinated with some epithelial folds. The duct was lacking the proper smooth muscle layer, although a few smooth muscle cells were scattered in the loose connective tissue of the subepithelial layer. The epithelium of the duct consisted of columnar principal cells and fewer basal cells, presenting pseudostratified appearence (Fig. 1). Any worth mentioning features could not be found by TEM in the cytoplasm of the epithelial cells except for a small accumulation of electron-dense granules occasionally found in the apical cytoplasm of some principal cells.

TEM examination of the ejaculatory duct often revealed nerve fibers located within the epithelium as well as in the subepithelial layer. Two types of intraepithelial nerves were detected with respect to the morphological features of synaptic vesicles (Fig. 2). One type (Fig. 2a) contained a large number of small clear vesicles $(30-50 \mathrm{~nm})$ and a few larger granular vesicles $(80-100 \mathrm{~nm})$ and, these fibers were classified as cholinergic according to the classical morphological criteria. These nerves were found predominantly in the lower half region of the epithelial layer. The other type of fibers (Fig. 2b), a terminal of which was often seen very close to the duct lumen, contained predominantly large granular vesicles $(100-150 \mathrm{~nm})$ and was regarded as peptidergic fibers. No membranous specialization could be found between the epithelial cells and the nerves described above.

\section{Histochemical study}

Positive reaction for $\mathrm{AChE}$ was striking in the whole surroundings of the ejaculatory duct, showing an intimate association with the epithelium (Fig. 3). 
TEM observations clearly revealed electron-dense $\mathrm{AChE}$ reactive material arranged in line with the axonal membrane of nerve fibers located within the epithelium (Fig. 4) and in the subepithelial layer. Nerve terminals or varicoses exhibiting the AChE stain were often observed to contain a number of small clear vesicles (Fig. 4b). In addition to the nerve fibers, blood capillaries in the subepithelial layer of the ejaculatory duct also showed positive AChE reaction (Fig. 3). TEM examination showed that this dense stain was localized just beneath the basal plasma membrane of the capillary endothelium.

\section{Immunohistochemical study}

Immunostaining for $\mathrm{TH}$ was carried out to examine the distribution of adrenergic nerve fibers; fibers stained for $\mathrm{TH}$ were not detected in the ejaculatory duct, except for the immediate surroundings of the blood vessels in the subepithelial tissue.

NPY-like immunoreactive nerve fibers were abundant in the epithelium of the ejaculatory duct. The immunoreactive fibers formed a dense nervous plexus just under the epithelium; some fibers originating in this plexus seemed to enter the epithelium (Fig. 5). Unlike SP - and CGRP like immunoreactive fibers mentioned below, the NPY-like immunoreactive nerve fibers did not extend their nerve terminals to the lumen of the duct.

Both SP- and CGRP-like immunoreactive nerve fibers were seen in moderate numbers within the epithelium as well as in the subepithelial connective tissue of the ejaculatory duct. Occasionally, these nerve fibers penetrated into the epithelial layer and appeared to reach the free surface of the epithelium of the duct (Fig. 6).

Nerve cell bodies immunoreactive for SP, CGRP or NPY were not found either within the epithelium or in the subepi- thelial layer of the ejaculatory duct. In addition, neural elements of the ejaculatory duct did not show any clear immunoreactivity for VIP.

\section{Discussion}

The presence of a unique nerve supply to the epithelium lining the ejaculatory duct of the monkey was definitely demonstrated in this investigation.

The histochemical study of $\mathrm{AChE}$ by LM revealed striking $\mathrm{AChE}$ reaction around the epithelium of the ejaculatory duct. TEM examination established the presence of fine granular reaction products of high electron-density in line with the axonal membrane of the nerves located both within and under the epithelium. Nerve terminals or varicoses with accumulation of small clear vesicles in their axoplasm were often found to be fringed with the AChE reaction, suggesting that these nerves may be regarded as cholinergic.

Almost all intraepithelial cholinergic nerves which were demonstrated so far were present in exocrine glands; functionally, they relate to the neural regulation of their glandular secretion (Yamamoto, 1966; Watari, 1967; Blood et al. 1976; Garret et al. 1977; Aiba et al. 1986). The existence of the cholinergic nerve fibers in close spatial association with the epithelium of the ejaculatory duct suggests an neural influence to the epjthelial activity such as secretion. In the epithelial cells of the ejaculatory duct, however, morphological features indicating secretory activity were not observed except for slight accumulation of presumable lysosomal granules which was occasionally seen in the apical cytoplasm of some principal cells. Therefore, a nural effect of the intraepithelial cholinergic nerves of the ejaculatory duct on some cellular activities other than secretion 
cannot be excluded at this time.

Not only the axonal membrane of some nerve fibers but also the extracellular region adjacent to the basal plasmalemma of blood capillary endothelium displayed the AChE reactivity. Such AChE reaction in the capillary endothelium has been already reported (Joó and Várkonyi, 1968; Flumerfelt et al. 1973; Kreutzberg and Tóth, 1974; Karcsú and Tóth, 1975). The reason of the occurrence of this enzyme activity in the capillary is still unknown.

Rich supply of NPY-like immunoreactive nerve fibers was observed in the ejaculatory duct. It is noteworthy that these immunoreactive nerves were arranged in a complex nervous plexus just beneath the epithelium, suggesting an intimate association of this plexus with the epithelium. So far, immunohistochemical studies available in the literature do not indicate the presence of a dense distribution of NPYcontaining nerves to the epithelium.

Since TH-like immunoreactive nerves could not be found within and around the epithelial layer, it is suggested that the intraepithelial NPY-containing nerves in the monkey ejaculatory duct do not consist noradrenaline. NPY-containing non-noradrenergic nerves have been already identified in various organs of some mammals (Furness et al. 1983; Lee et al. 1985; Mattiasson et al. 1985; Morris et al. 1985, 1986; Macrae et al. 1986; McLachlan and Llewellyn-Smith, 1986; Wang et al. 1987; Papka and Traurig, 1988).

Concerning the function of the NPYcontaining nerves in the peripheral nervous system, Stjernquist and his coworkers (1983) suggested that NPY exerts presynaptic inhibition on release of $\mathrm{ACh}$ from the cholinergic nerve terminals in the rat uterine cervix. The NPY-containing nerves observed in the epithelium of the monkey ejaculatory duct may have an inhibitory effect on the cholinergic nerves abundantly distributing in the ductural epithelium.
Coexistence of immunoreactivity for NPY and for choline acetyltransferase has been demonstrated in a single neuron in the small intestine of the guinea-pig (Furness et al. 1984) and in the parasympathetic ganglia of the rat (Leblanc et al. 1987). Therefore, another possibility must be taken in consideration that the NPYcontaining nerves in the ejaculatory duct may be cholinergic in nature.

The immunohistochemical examination has revealed that there is a moderate supply to the ejaculatory duct of nerve fibers immunoreactive for SP and CGRP. These fibers occasionally appeared to pass through the whole layer of the epithelium; thus, their nerve terminals may abut upon the lumen of the duct. Some of the intraepithelial nerves which were observed in TEM study may correspond to the SPand/or CGRP-like immunoreactive nerves.

Intraepithelial occurrence of SP - and/or CGRP-cotaining nerves has been reported for several organs, such as the urinary tract including the bladder (Alm et al. 1978; Sikri et al. 1981; Iwanaga et al. 1985; Yokokawa et al. 1986), the respiratory tract (Uddman et al. 1983 and 1985; Hisa et al. 1985; Cadieux et al. 1986; Takemoto et al. 1986) and the skin (Björklund et al. 1986; Alvarez et al. 1988). All these SPand/or CGRP immunoreactive nerves were found to be associated with the sensory function. Hence, similar functional interpretation may be given to intraepithelial SP - and/or CGRP-immunoreactive nerves of the ejaculatory duct; it may be speculated that the intraepithelial SP- and/or CGRP-containing nerves of the ejaculatory duct participate in conducting afferently sensory information, including special sensation which accompanies the ejaculation. These nerves penetrate the epithelium or extend occasionally to the ductural lumen, and this distribution is favorable for receiving sensory information from the duct.

Altogether, the present study demon- 
strated the intraepithelial location of cholinergic nerves, and NPY-, SP- and CGRP-containing nerves in the ejaculatory duct of the monkey. However, much remains to be investigated concerning the origin and function of these nerves.

Acknowledgments: The author wish to thank Prof. M. Murakami, Kurume University School of Medicine, for his helpful comments on the manuscript, and also thank Dr. T. Inokuchi, Kurume University School of Medicine, and Prof. K. Ando, Kyushu Sangyo University, for their useful technical advices.

\section{References}

Aiba, T., Yokoyama, R., Satoh, H., Hada, H., Izuchi, H. et al. (1986). The ultrastructure of intrapithelial nerve fibers in the bulbourethral gland of the castrated rat. J. Kurume Med. Ass. 49, 1466-1477 (in Japanese).

Alm, P., Alumets, J., Brodin, E., HÅkanson, R., Nilsson, G. et al. (1978). Peptidergic (substance $\mathrm{P}$ ) nerves in the genito-urinary tract. Neuroscience 3, 419-425.

Alvarez, F. J., Cervantes, C., Villalba, R., Blasco, I., Martinez-Murillo, R. et al. (1988). Immunocytochemical analysis of calcitonin generelated peptide and vasoactive intestinal polypeptide in Merkel cells and cutaneous free nerve endings of cats. Cell Tissue Res. 254, 429-437.

Ando, K. (1988). Distribution and origin of vasoactive intestinal polypeptide (VIP)-immunoreactive, acetylcholinesterase-positive and adrenergic nerves of the cerebral arteries in the bent-winged bat (Mammalia: Chiroptera). Cell Tissue Res. 251, 345-351.

Aumúller, G. (1979). Prostate gland and seminal vesicles. Handbuch der mikroskopischen Anatomie des Menschen VII/ 6 .

Björklund, H., Dalsgaard, C. J., Jonsson, C. E. and Hermansson, A. (1986). Sensory and autonomic innervation of non-hairy and hairy human skin. Cell Tissue Res. 243, 51-57.

Blood, L. A., Kennerson, A.R. and van Lennep, E. W. (1977). Morphology and histochemistry of the mandibular gland of the Australian brush-tail possum Trichosurus vulpecula
(Marsupialia). Anat. Rec. 188, 489-508.

BurkL, W. (1953). Über die Entwicklung der Samenblase und der Ampulle des Ductus deferens beim Menschen. Z. Anat. Entwicklungsgesh. 117, 155-165.

Cadieux, A., Springall, D. R., Mulderry, P.K., Rodrigo, J., Ghatei, M.A. et al. (1986). Occurence, distribution and ontogeny of CGRP immunoreactivity in the rat lower respiratory tract: effect of capsaicin treatment and surgical denervations. Neuroscience 19, 605-627.

Cossu, M., Marcello, M.F., Usai, E., Riva, F. T. and Riva, A. (1983). Fine structure of the epithelium of the human ejaculatory duct. Acta Anat. 116, 225-233.

Felix, W. (1910). Zur Anatomie des ductus ejaculatorius, der ampulla ductus deferentis und der vesicula seminalis des erwachsenen Mannes. Anat. H. 17, 1-54.

Flumerfelt, B. A., Lewis, P.R. and Gwyn, D.G. (1973). Cholinesterase activity of capillaries in the rat brain. A light and electron microscopic study. Histochem. J. 5, 67-77.

Furness, J. B., Costa, M., Emson, P.C., HÅkanson, R., Moghimzadeh, E., et al. (1983). Distribution, pathways and reactions to drug treatment of nerves with neuropeptide $\mathrm{Y}$ - and pancreatic polypeptide-like immunoreactivity in the guinea-pig digestive tract. Cell Tissue Res. 234, 71-92.

Furness, J. B., Costa, M. and Keast, J. R. (1984). Choline acetyltransferase- and peptide immunoreactivity of submucous neurons in the small intestine of the guinea-pig. Cell Tissue Res. 237, 329-336.

GARRET, J.R. (1977). The autonomic innervation of rabbit salivary glands studied electron $\mathrm{mi}$ croscopically after 5-hydroxydopamine administration. Cell Tissue Res. 178, 551-562.

Hisa, Y., Sato, F., Fukui, K., Ibata, Y. and Mizukoshi, O. (1985). Substance P nerve fibers in the canine larynx by PAP immunohistochemistry. Acta Otolaryngol. 100, 128133.

Iwanaga, T., Fujita, T. and Yanaihara, N. (1985). Nerve fibers in the urethral mucosa of canine penis are immunoreactive for both substance $\mathrm{P}$ and calcitonin gene-related peptide. Arch. Histol. Jap. 48, 547-554.

Joó, F. and VÁrkonyi, T. (1969). Correlation between the cholinesterase activity of capillaries and the blood-brain barrier in the rat. Acta biol. Acad. Sci. Hung. 20, 359-372. 
Karcsú, S. and Toth,L. (1975). Fine structural localization of acetylcholinesterase in capillaries surrounding the area postrema. (1975). Brain Res. 95, 137-141.

Kreutzberg, G. W. and Tóth, L. (1974). Dendric secretion: a way for the neuron to communicate with the vasculature. Naturwissenschaften $61,37$.

Leblanc, G. G., Trimmer, B. A. and Landis, S.C. (1987). Neuropeptide Y-like immunoreactivity in rat cranial parasympathetic neurons: coexistence with vasoactive intestinal peptide and choline acetyltransferase. Proc. Natl. Acad. Sci. USA. 84, 3511-3515.

Lee, Y., Shiosaka, S., Emson, P.C., Powell, J.F., Sмiтн, et al. (1985). Neuropeptide Y-like immunoreactive structures in the rat stomach with special reference to the noradrenaline neuron system. Gastroenterology 89, 118-126.

LowsLeY, O.S. (1912). The development of the human prostate gland with reference to the development of other structures at the neck of the urinary bladder. Am. J. Anat. 13, 299-349.

Macrae, I. M., Furness, J. B. and Costa, M. (1986). Distribution of subgroups of noradrenaline neurons in the coeliac ganglion of the guineapig. Cell Tissue Res. 244, 173-180.

Mattiasson, A., Ekblad, E., Sundler, F. and Uvelius, B. (1985). Origin and distribution of neuropeptide $\mathrm{Y}-$, vasoactive intestinal polypeptide and substance $\mathrm{P}$-containing nerve fibers in the urinary bladder of the cat. Cell Tissue Res. 239, 141-146.

McLachlan, E. M. and Llewellyn-Smith, I. J. (1986). The immunohistochemical distribution of neuropeptide $\mathrm{Y}$ in lumbar pre- and paravertebral sympathetic ganglia of the guineapig. J. Auton. Nerv. Syst. 17, 313-324.

Morris, J. L., Gibbins, I. L., Furness, J. B., Costa, M. and Murphy, R. (1985). Co-localization of neuropeptide $Y$, vasoactive intestinal polypeptide and dynorphin in non-noradrenergic axons of the guinea pig uterine artery. Neurosci. Lett. 62, 31-37.

Morris, J. L., Murphy, R., Furness, J.B. and Costa, M. (1986). Partial depletion of neuropeptide $\mathrm{Y}$ from noradrenergic perivascular and cardiac axons by 6 -hydroxydopamine and reserpine. Regul. Pept. 13, 147-162.

Murakami, M., Yokoyama, R., Nishida, T. and SАтон, H. (1988). Scanning and transmission electron microscopic observations of the ductus ejaculatorius in the Japanese monkey, with special reference to epithelial phagocytosis of spermatozoa. Acta Anat. Nippon. 63, 361 (abstract in Japanese).

Nagatsu, I. (1983). Immunohistochemistry of biogenic amines immunoenzyme-histochemistry of catecholamine-synthesizing enzymes. In Methoda in Biogenic Amine Research, eds. Parves, S., Nagatsu, T., Nagatsu, I. and Parves H. pp. 873-909. Amsterdam: Elsevier.

NoButa, Y. (1949). Innervation of the prostate, the ejaculatory duct, the prostatic utricle and the prostatic urethra. Tohoku Med. J. 39, 5-14.

PAPKa, R.E. and Traurig, H.H. (1988). Distribution of subgroups of neuropeptide Y-immunoreactive and noradrenergic nerves in the female rat uterine cervix. Cell Tissue Res. 252, 533-541.

Sikri, K. L., Hoyes, A. D., Barber, P. and JAgessar, H. (1981). Substance P-like immunoreactivity in the intramural nerve plexuses of the guinea pig ureter: a light and electron microscopical study. J. Anat. 133. 425-442.

Stjernquist, M., Emson, P., Owman, C., Sjöberg, N. O., Sundler, F. et al. (1983). Neuropeptide Y in the female reproductive tract of the rat. Distribution of nerve fibers and motor effects. Neurosci. Lett. 39, 279-284.

TAgo, H., Kimura, H. and MaEda, T. (1986). Visualization of detailed acetylcholinesterase fiber and neuron staining in rat brain by a sensitive histochemical procedure. J. Histochem. Cytochem. 34, 1431-1438.

Takemoto, S., Wada, S., Maeyama, T. and Watanabe, S. (1987). Substance P immunoreactive nerve fibers of the canine laryngeal mucosa. Otolaryngol. Head Neck Surg. 97, 39-46.

Uddman, R., Malm, L. and Sundler, F. (1983). Substance P-containing nerve fibers in the nasal mucosa. Arch. Otorhinolaryngol. 238, 9-16.

Uddman, R., Luts, A. and Sundler, F. (1985). Occurence and distribution of calcitonin generelated peptide in the mammalian respiratory tract and middle ear. Cell Tissue Res. 241, 551-555.

Wang, Y-N., McDonald, J. K. and Wyatt, R. J. (1987). Immunocytochemical localization of neuropeptide $Y$ like immunoreactivity in adrenergic and non-adrenergic neurons of the rat gastrointestinal tract. Peptides 8, 145-151. 
WAtari, N. (1968). Fine structure of nervous elements in the pancreas of some vertebrates. Z. Zellforsch. 85, 291-314.

Yамамото, T. (1966). On the fine structure of the terminal portion of nasal gland in guineapig, with special reference to the interrelationship between glandular cells and nerve endings. Arch. Histol. Jap. 27, 311-325.

Yokokawa, K., Tohyama, M., Shiosaka, S., Shiotani, Y.,SonodA, T. et al. (1986). Distribution of calcitonin gene-related peptide-containing fibers in the urinary bladder of the rat and their origin. Cell Tissue Res. 244, 271-278. 


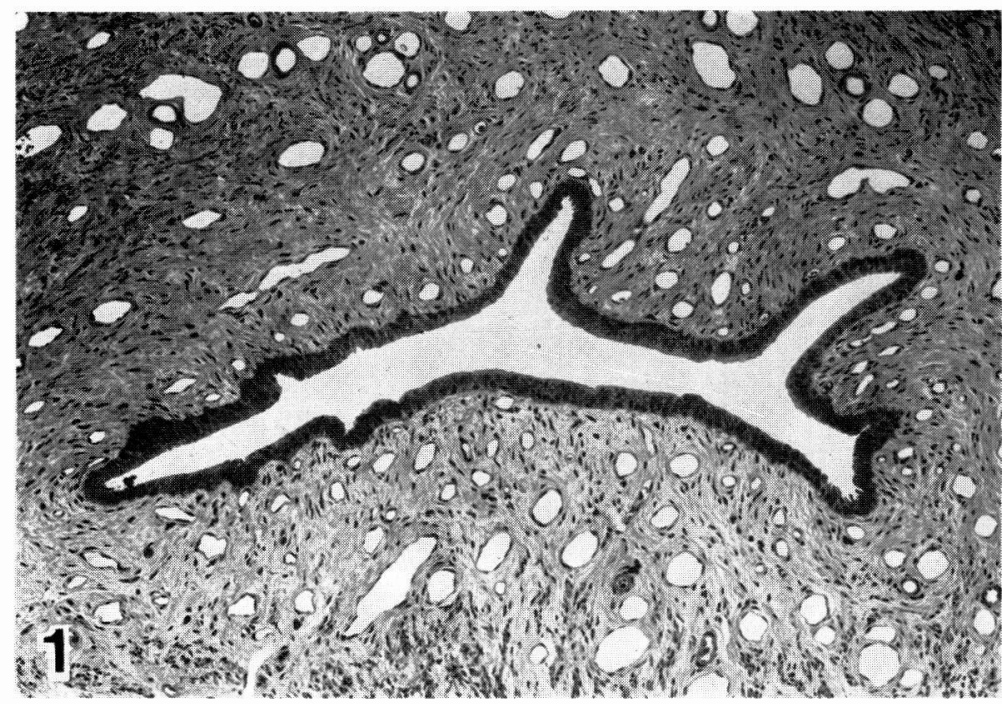

Fig. 1 LM view showing a cross section of the ejaculatory duct. The ejaculatory duct is composed of pseudostratified epithelium and subepithelial fibrous connective tissue in which some smooth muscle cells are scattered. The duct lacks the proper muscle layer. Toluidine blue staining.

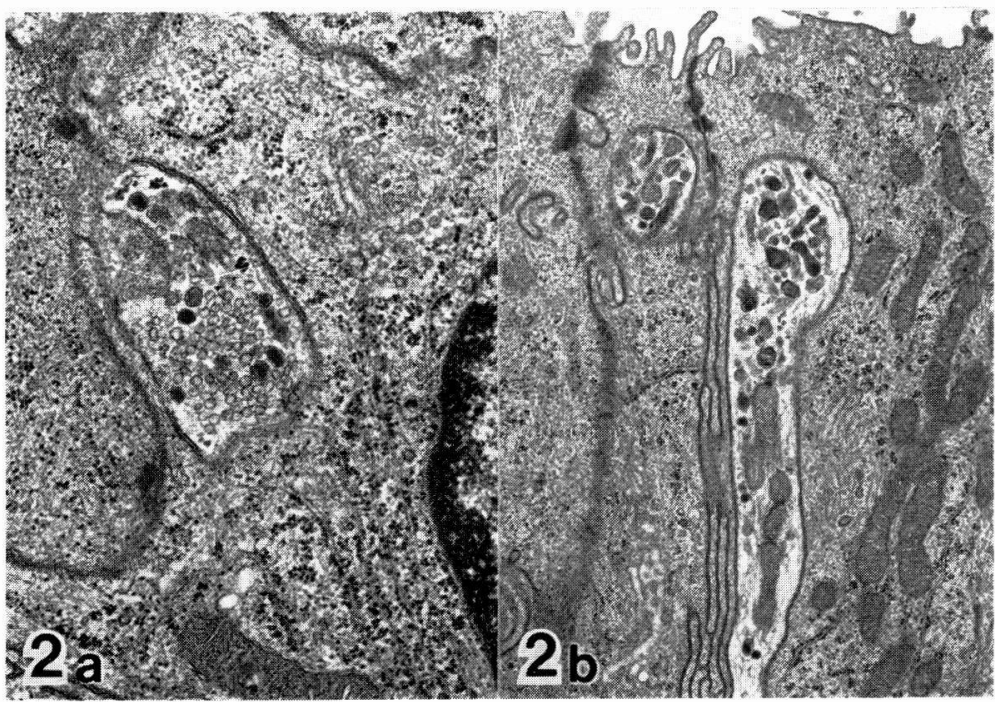

Fig. 2a) TEM view showing an intraepithelial nerve fiber. The nerve contains many small clear vesicles and a few larger granular ones, indicating possible cholinergic nature of this nerve. $\times 20,000$

b) TEM view of another intraepithelial nerve fiber stretching up to an intercellular space just under the free surface of the epithelium. This type of nerve fiber contains predominantly large granular vesicles in the termial, and therefore, may be peptidergic in nature. $\times 12,000$ 


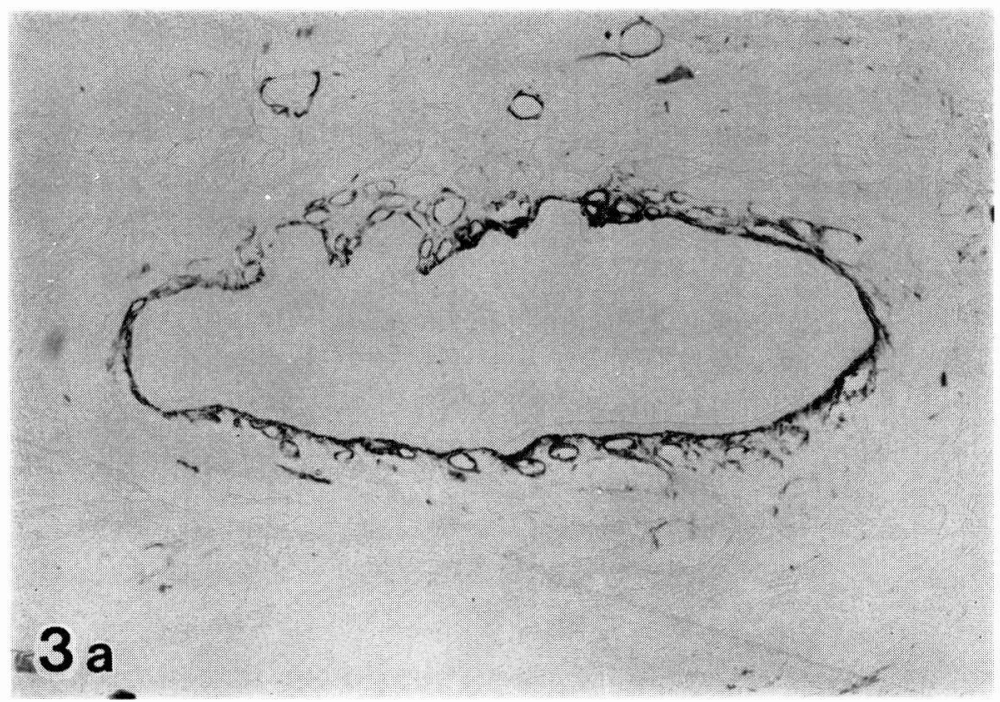

Fig. 3a) LM view showing AChE reaction in the ejaculatory duct. The epithelium of the duct is rimmed entirely by dense reaction products.

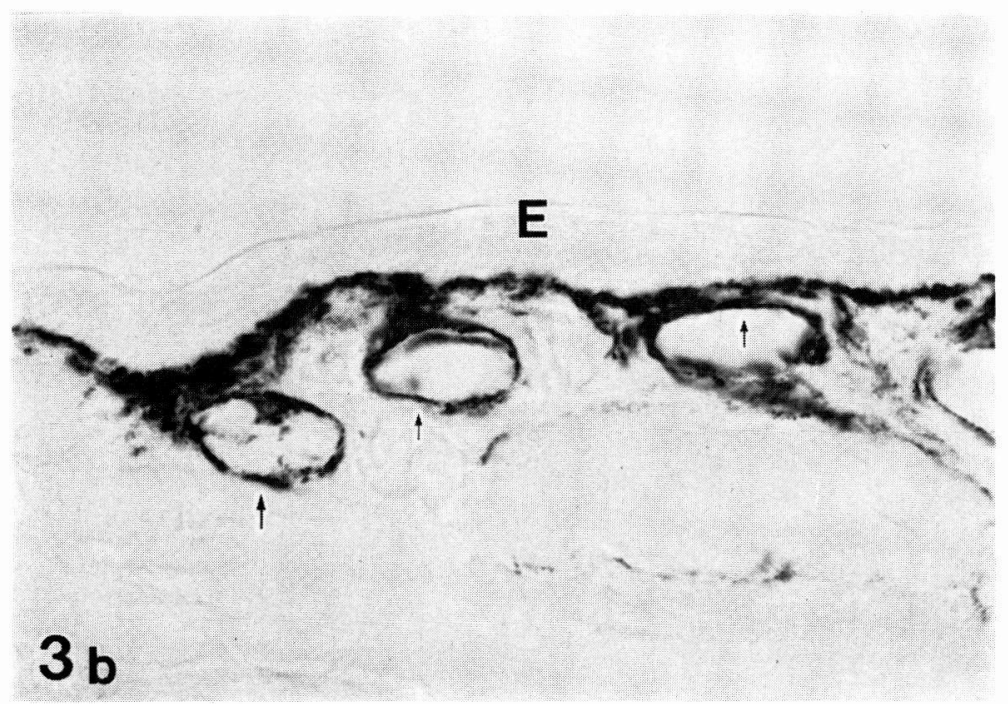

Fig. 3b) Higher magnification view of a part of Fig. $3(a)$. $\mathrm{AChE}$ reaction is seen in close association with the epithelium. Similar positive reaction is recognized also around the blood capillaries in the subepithelial layer (arrows). E: epithelium 


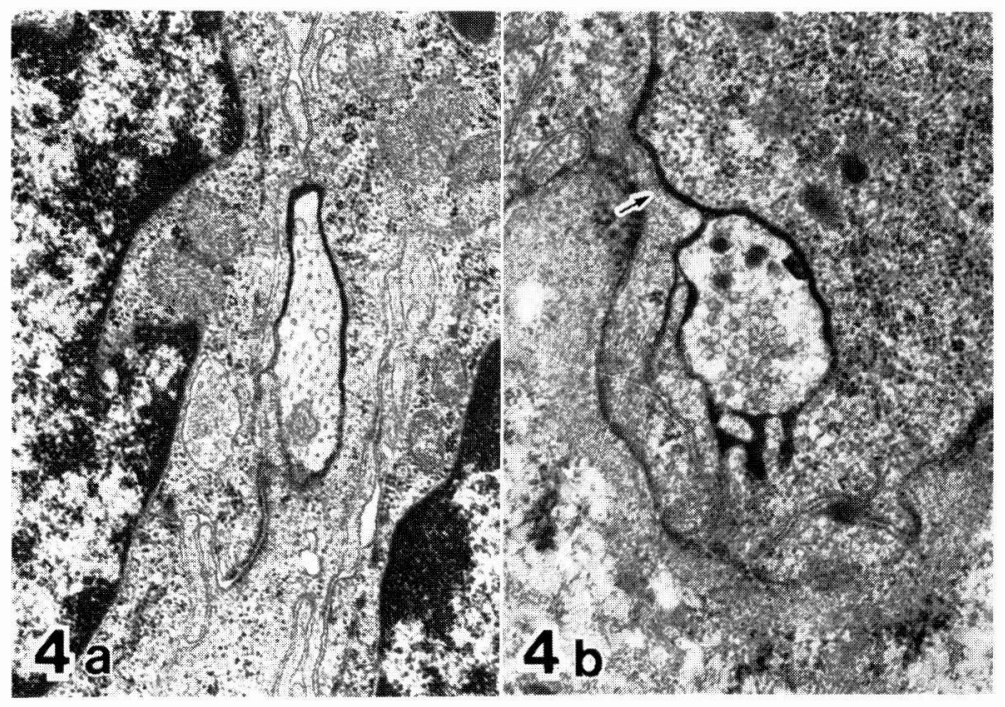

Fig. 4a) TEM view showing an intraepithelial AChE-positive nerve. Electron-dense reaction is seen continuously in line with the axonal membrane. $\times 20,000$

b) TEM view showing another $\mathrm{AChE}$-positive nerve located basally in the epithelium. $\mathrm{AChE}$ reaction is seen in the intercellular space as well as along the axonal membrane (arrow). Note an aggregation of small clear vesicles and a few large granular ones in the $\mathrm{AChE}$-positive nerve. $\times 25,000$

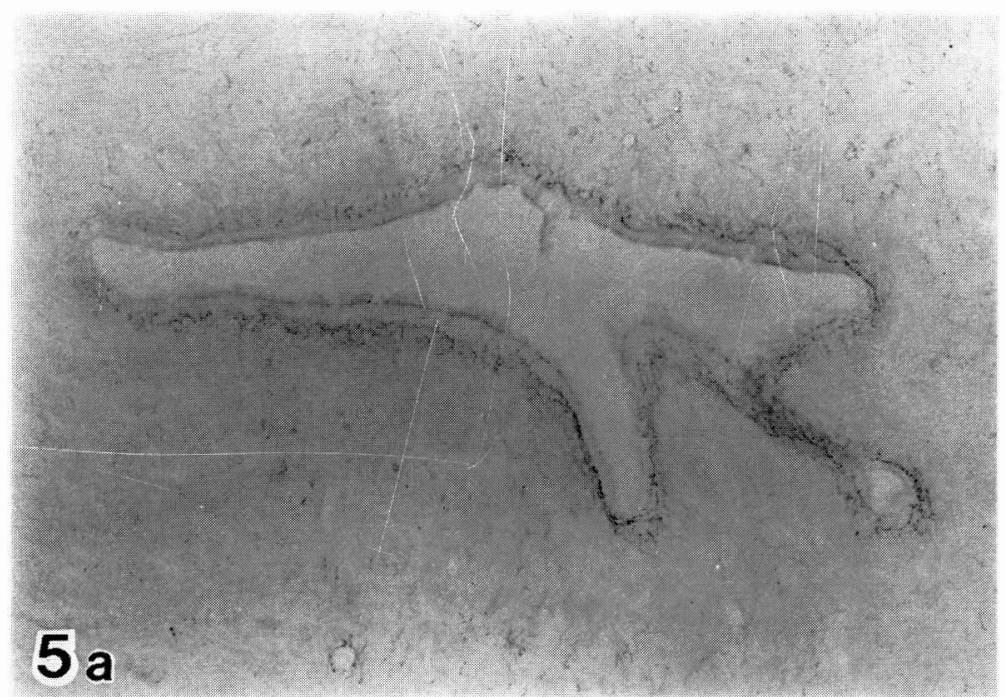

Fig. 5a) LM view showing NPY-like immunoreactive nerve fibers distributed in the ejaculatory duct. The positive fibers are abundant especially around the epithelium, showing intimate association with the epithelium. E:epithelium 


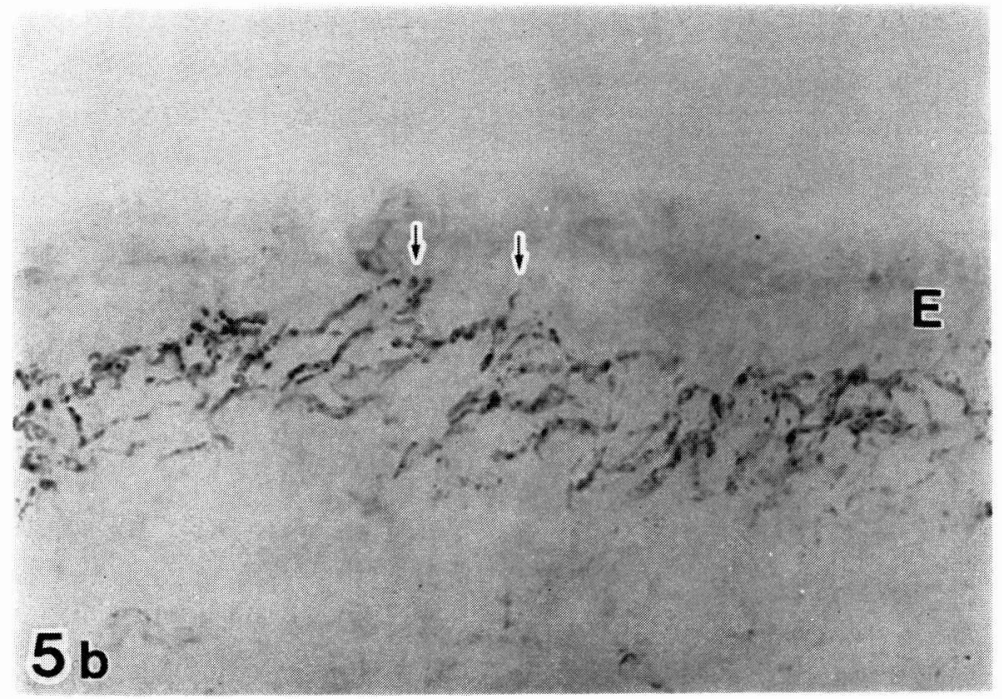

Fig. 5b) Higher magnification view of a part of Fig. $5(a)$. NPY-like immunoreactive fibers are making a dense plexus just under the epithelium. Some fibers appear to enter the epithelium (arrows).

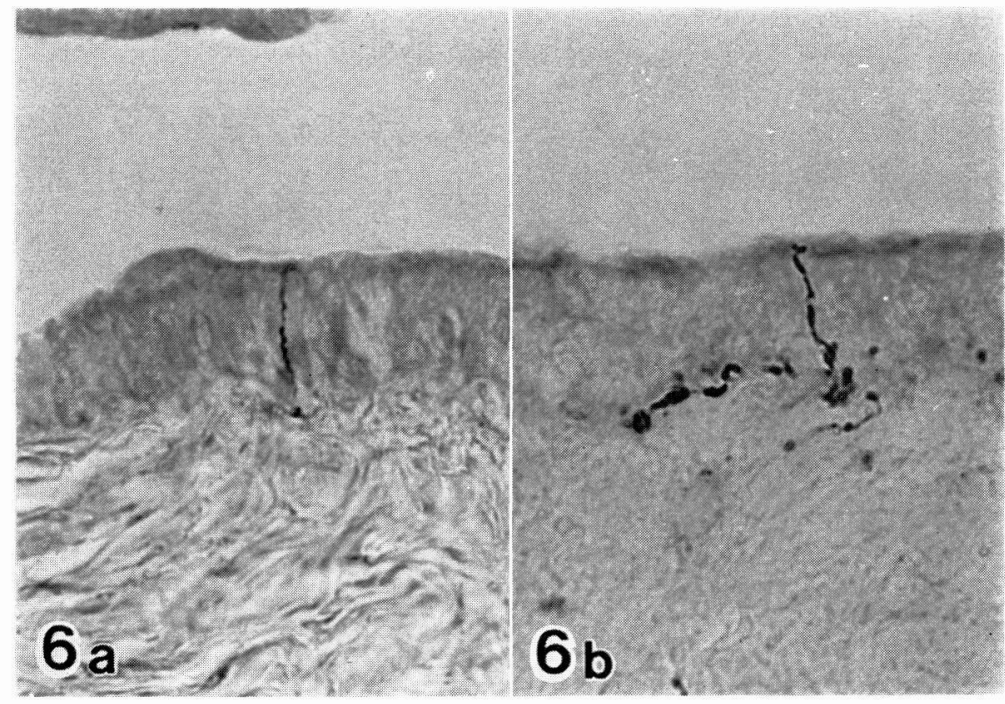

Fig. $6 \mathrm{LM}$ view showing an intraepithelial nerve fiber immunoreactive for SP $(a)$ and CGRP $(b)$. Both types of fibers can be traced close to the surface of the epithelium. 